\title{
Critical role of domain crystallinity, domain purity and domain interface sharpness for reduced bimolecular recombination in polymer solar cells
}

\author{
Swaminathan Venkatesan ${ }^{1}$, Jihua Chen ${ }^{2}$, Evan C. Ngo ${ }^{1}$, Ashish Dubey ${ }^{1}$, Devendra Khatiwada ${ }^{1}$, \\ Cheng Zhang ${ }^{3}$, and Qiquan Qiao ${ }^{1 *}$ \\ ${ }^{1}$ Center for Advanced Photovoltaics, Department of Electrical Engineering and Computer \\ Science, South Dakota State University, Brookings, SD, USA \\ qiquan.qiao@sdstate.edu \\ ${ }^{2}$ Center for Nanophase Materials Sciences, Oak Ridge National Laboratory, Oak Ridge,TN \\ 37831, USA \\ ${ }^{3}$ Department of Chemistry and Biochemistry, South Dakota State University, Brookings, SD, \\ USA
}

\begin{abstract}
Inverted bulk heterojunction solar cells were fabricated using poly(3-hexylthiophene) (P3HT) blended with two different fullerene derivatives namely phenyl-C61-butyric acid methyl ester $\left(\mathrm{PC}_{60} \mathrm{BM}\right)$ and indene- $\mathrm{C}_{60}$ bis-adduct $\left(\mathrm{IC}_{60} \mathrm{BA}\right)$. The effect of annealing temperatures on the morphology, optical and structural properties were studied and correlated to differences in photovoltaic device performance. It was observed that annealing temperature significantly improved the performance of P3HT: $\mathrm{IC}_{60} \mathrm{BA}$ solar cells while P3HT:PC${ }_{60} \mathrm{BM}$ cells showed relatively less improvement. The performance improvement is attributed to the extent of fullerene mixing with polymer domains. Energy filtered transmission electron microscopy (EFTEM) and x-ray diffraction (XRD) results showed that ICBA mixes with disordered P3HT much more readily than $\mathrm{PC}_{60} \mathrm{BM}$ which leads to lower short circuit current density and fill factor for $\mathrm{P} 3 \mathrm{HT}: \mathrm{IC}_{60} \mathrm{BA}$ cells annealed below $120^{\circ} \mathrm{C}$. Annealing above $120^{\circ} \mathrm{C}$ improves the crystallinity of $\mathrm{P} 3 \mathrm{HT}$ in case of $\mathrm{P} 3 \mathrm{HT}: \mathrm{IC}_{60} \mathrm{BA}$ whereas in $\mathrm{P} 3 \mathrm{HT}: \mathrm{PC}_{60} \mathrm{BM}$ films, annealing above $80^{\circ} \mathrm{C}$ leads to negligible change in crystallinity. Crystallization of P3HT also leads to higher
\end{abstract}


domain purity as seen EFTEM. Further it is seen that cells processed with additive nitrobenzene (NB) showed enhanced short circuit current density and power conversion efficiency regardless of the fullerene derivative used. Addition of NB led to nanoscale phase separation between purer polymer and fullerene domains. Kelvin probe force microscopy (KPFM) images showed that enhanced domain purity in additive casted films led to a sharper interface between polymer and fullerene. Enhanced domain purity and interfacial sharpness led to lower bimolecular recombination and higher mobility and charge carrier lifetime in NB modified devices.

Keywords: polymer solar cells, bimolecular recombination, domain crystallinity, domain purity and domain interface sharpness

\section{Introduction}

Due to increased demand for clean energy and depletion of fossil fuels, alternative energy sources such as solar and wind are of interest currently. Organic semiconductors have gained significant amount of interest for photovoltaic applications in the last several decades due to their lower $\operatorname{cost}^{1}$ and processibility from solution for lightweight and flexible devices ${ }^{2}$. Polymerfullerene bulk heterojunction (BHJ) solar cells have shown photovoltaic efficiencies up to $11 \%{ }^{3}$, ${ }^{4}$. Nanomorphology plays a crucial role in BHJ solar cells as it dictates both charge generation and transport ${ }^{5-7}$. Nanomorphological features such as donor/acceptor crystallinity ${ }^{8}$, vertical/lateral phase separation ${ }^{9,10}$, domain purity ${ }^{11}$, orientation ${ }^{12}$ and domain interfaces ${ }^{13}$ can be tailored by optimizing the processing conditions to enhance device conversion efficiencies. Processing parameters such as solvent selection ${ }^{8,14,15}$, annealing temperature ${ }^{16}$, donor-acceptor mixing ratio 17,18 , and coating techniques can be fine-tuned to attain high photovoltaic performance.

Molecular miscibility between polymer and fullerene is critical to acquire homogenous phase separation between polymer and fullerene components leading to efficient exciton dissociation ${ }^{19}$. However higher miscibility can lead to highly intermixed domains preventing ordering of polymer chains. These highly intermixed amorphous domains have shown to possess poor charge transport ${ }^{20}$. It is desired to have pure polymer domains having sharp interface between polymer and fullerene phase (less intermixing at domain boundaries) to improve charge 
transport and suppress trap assisted losses ${ }^{21}$. Several studies have focused on the mixing of donor polymers and fullerene blend films and have shown that domain purity and crystallinity ${ }^{5}$ 22, 23 plays an important role in enhancing device performance, but the physics behind efficient charge transport correlated to nanoscale morphology is still elusive. Further, the processing parameters required to achieve ideal morphology is dependent upon the material selection and needs to be studied. Such an insight will be beneficial to attain high power conversion efficiency at large scale.

P3HT:PCBM solar cells have been widely studied ${ }^{24}$ in the past decade and efficiencies of $4-5 \%$ have been regularly achieved. Device efficiencies were further improved to $5-7 \%{ }^{25,26}$ by using a bis-adduct fullerene derivative namely indene- $\mathrm{C}_{60}$ bisadduct $\left(\mathrm{IC}_{60} \mathrm{BA}\right)$ resulting in higher open circuit voltage due to the higher LUMO level in ICBA. One of the most prominent approaches to improve efficiency in P3HT based blends has been slow drying of cast films. Slow drying leads to structural ordering of P3HT and diffusion of fullerene to achieve nanoscale phase separation between crystalline P3HT and fullerene domains. This approach has demonstrated efficient solar cells, however, is not practical for roll to roll processing. Lower boiling point solvents are preferred to increase throughput and thickness uniformity for roll to roll printing implementation ${ }^{27}$. Further it has been shown that mixing behavior of fullerene with P3HT is dependent upon the fullerene derivative used ${ }^{28}$. There exists a need for understanding the correlation between processing conditions and resulting morphology and between complex nanoscale morphological features and charge transport/recombination to achieve faster commercialization of low cost plastic solar cells.

In this study we found that mixing behavior of $\mathrm{P} 3 \mathrm{HT}$ and fullerene is dependent upon the fullerene derivative used. ICBA was found to mix with P3HT more readily and the blend films require higher thermal energy to segregate into pure polymer and fullerene phases. Inclusion of additives that are poor solvents for P3HT and good solvent for fullerene lead to formation of ideal morphology consisting of interconnected pure polymer domains that have sharper interfaces for exciton dissociation and lower bimolecular recombination.

\section{Results and Analysis}

The chemical structures of the donor and acceptor materials used are shown in Figure 1a. The experimental procedures for film deposition, device fabrication and characterization are 
given in detail in Supporting Information. To evaluate the effect of annealing on the optical properties and structural properties of $\mathrm{P} 3 \mathrm{HT}: \mathrm{PC}_{60} \mathrm{BM}$ and $\mathrm{P} 3 \mathrm{HT}: \mathrm{IC}_{60} \mathrm{BA}$ blend films, UVVisible absorption and XRD diffraction spectra were taken as shown in Figure 1b and Figure 1c respectively. In both cases films without thermal annealing (as deposited) showed a single peak at $476 \mathrm{~nm}$. For P3HT: $\mathrm{PC}_{60} \mathrm{BM}$ films annealing at and above $80^{\circ} \mathrm{C}$, the peak red shifted to $504 \mathrm{~nm}$ and also showed formation of vibronic shoulders around $545 \mathrm{~nm}$ and $595 \mathrm{~nm}$. These vibronic shoulders formation at $545 \mathrm{~nm}$ and $595 \mathrm{~nm}$ is related to intrachain and interchain packing of P3HT respectively ${ }^{29-31}$. When the $\mathrm{P} 3 \mathrm{HT}: \mathrm{PC}_{60} \mathrm{BM}$ films were subjected to thermal annealing these shoulders start to form suggesting interchain and intrachain stacking. In particular the intensity of the shoulder at $595 \mathrm{~nm}$ (0-0 transition) was low in the as deposited films indicating poor packing between chains. When the films were annealed these shoulders become more pronounced which indicated that the $\mathrm{P} 3 \mathrm{HT}$ chains assemble to form ordered chains as supported by the XRD spectra. However in P3HT: $\mathrm{IC}_{60} \mathrm{BA}$ films, the vibronic shoulder at $595 \mathrm{~nm}$ had low intensities even when annealed below $120^{\circ} \mathrm{C}$. The absorption peaks of $\mathrm{P} 3 \mathrm{HT}$ : $\mathrm{IC}_{60} \mathrm{BA}$ films also stayed at $\sim 468 \mathrm{~nm}$ and did not show any red shift which represents less crystalline and defective P3HT when blended with $\mathrm{IC}_{60} \mathrm{BA}$ up to $120^{\circ} \mathrm{C}$. Annealing at and above $120^{\circ} \mathrm{C}$ led to red shift of the peak to $486 \mathrm{~nm}$ and annealing beyond $150^{\circ} \mathrm{C}$, the vibronic shoulder at $595 \mathrm{~nm}$ became more pronounced leading to the conclusion that higher temperatures were required for $\mathrm{P} 3 \mathrm{HT}$ chains to pack in P3HT: $\mathrm{IC}_{60} \mathrm{BA}$ films. This could also be easily observed from the color of the film. The as deposited films had an orange color for both. $\mathrm{P} 3 \mathrm{HT}: \mathrm{PC}_{60} \mathrm{BM}$ films turned purple when annealed at $80^{\circ} \mathrm{C}$ and above. However the orange color was still visible in P3HT: $\mathrm{IC}_{60} \mathrm{BA}$ films when annealing temperatures were below $120^{\circ} \mathrm{C}$ which indicated that ICBA prevented P3HT chains to order at lower annealing temperatures. Figure 1c and d show the XRD spectra of $\mathrm{P} 3 \mathrm{HT}: \mathrm{PC}_{60} \mathrm{BM}$ and $\mathrm{P} 3 \mathrm{HT}: \mathrm{IC}_{60} \mathrm{BA}$ films. A peak at $5.4^{\circ}$ was observed for all films corresponding to $\left(\begin{array}{lll}1 & 0 & 0\end{array}\right)$ diffraction of $\mathrm{P} 3 \mathrm{HT}^{32} .2 \theta=5.4^{\circ}$ relates to d-spacing of $1.61 \mathrm{~nm}$ which corresponds to distance between hexyl side chains of P3HT. A small second order $\left(\begin{array}{lll}2 & 0 & 0\end{array}\right)$ diffraction peak was also observed at $10.5^{\circ}$ in annealed films. The as deposited P3HT:PC ${ }_{60} \mathrm{BM}$ and $\mathrm{P} 3 \mathrm{HT}: \mathrm{IC}_{60} \mathrm{BA}$ show broad peaks indicating higher disorder and smaller crystallite size of P3HT phase. Annealing the films led to narrowing of ( $\left(\begin{array}{lll}1 & 0 & 0\end{array}\right)$ peak which indicated increased crystallite size of P3HT phase. In P3HT: $\mathrm{PC}_{60} \mathrm{BM}$ negligible change is seen in the XRD peaks when films were annealed above $80^{\circ} \mathrm{C}$. However in the case of P3HT: $\mathrm{IC}_{60} \mathrm{BA}$ broad peaks are observed for as 
deposited and $80^{\circ} \mathrm{C}$ annealed films. With increasing annealing temperatures above $100^{\circ} \mathrm{C}$ the peaks get narrower up to $150^{\circ} \mathrm{C}$ after which negligible changes were seen as shown in the inset. The trend in peak narrowing in P3HT:ICOBA is similar to that observed in the vibronic shoulder formation seen in optical absorption spectra. Hence higher annealing temperatures were required for $\mathrm{P} 3 \mathrm{HT}$ to aggregate into larger crystallites in $\mathrm{P} 3 \mathrm{HT}: \mathrm{IC}_{60} \mathrm{BA}$ blend films.

(a)

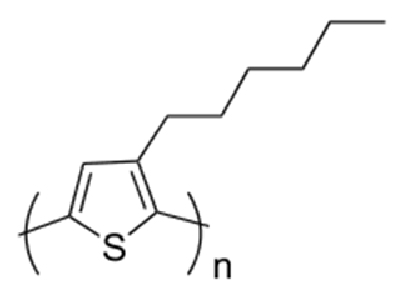

P3HT

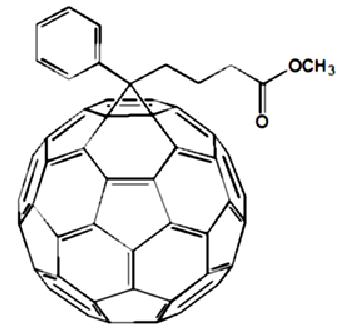

$\mathrm{PC}_{60} \mathrm{BM}$

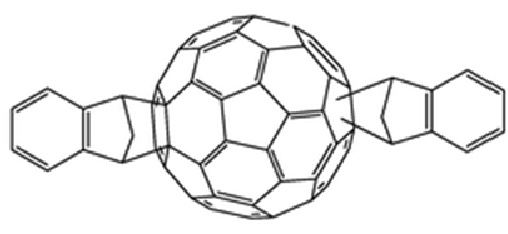

$\mathrm{IC}_{60} \mathrm{BA}$
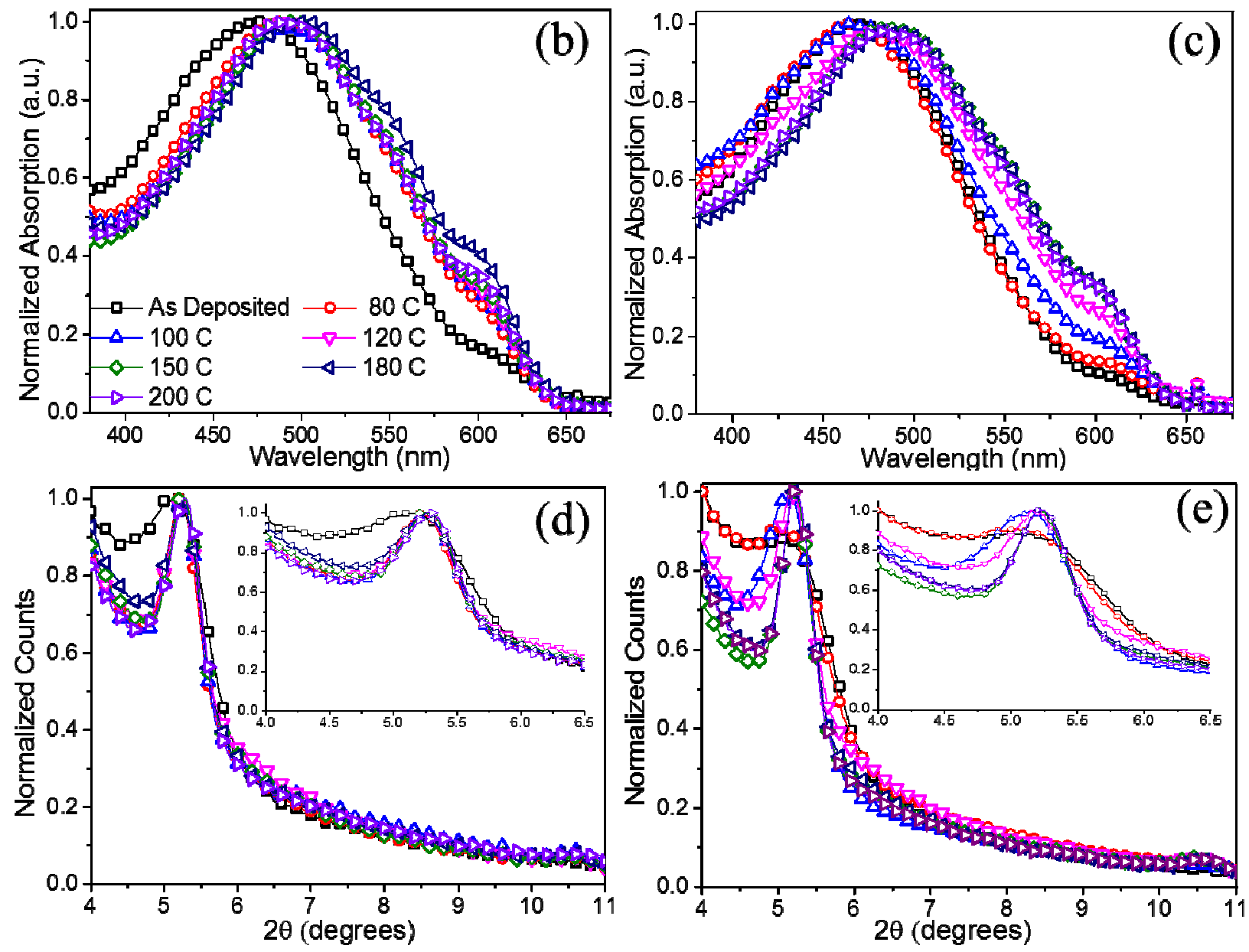

Figure 1 (a) Chemical structure of $\mathrm{P} 3 \mathrm{HT}, \mathrm{PC}_{60} \mathrm{BM}$ and $\mathrm{IC}_{60} \mathrm{BA}$. UV-Visible absorption spectra of (b) P3HT: $\mathrm{PC}_{60} \mathrm{BM}$ and (c) P3HT: $\mathrm{IC}_{60} \mathrm{BA}$ films with different annealing temperatures. X-ray 
diffraction spectra of (d) P3HT: $\mathrm{PC}_{60} \mathrm{BM}$ and (e) P3HT: $\mathrm{IC}_{60} \mathrm{BA}$ films with different annealing temperatures. Inset shows the region from $4^{\circ}$ to $6.5^{\circ}$

To observe the changes in the nanoscale purity of $\mathrm{P} 3 \mathrm{HT}$ and $\mathrm{PC}_{60} \mathrm{BM} / \mathrm{IC}_{60} \mathrm{BA}$ domains, energy filtered transmission electron microscopy (EFTEM) was performed to obtain donor and acceptor maps. The donor and acceptor maps were overlaid to find the donor purity in as deposited and thermally annealed $\mathrm{P} 3 \mathrm{HT}: \mathrm{PC}_{60} \mathrm{BM}$ and $\mathrm{P} 3 \mathrm{HT}: \mathrm{IC}_{60} \mathrm{BA}$ films as shown in Figure 2. The orange color in EFTEM composite maps corresponds to donor purity (sulfur) and green color shows the acceptor purity. Grey areas in the map are due to thickness variations in the films. In the as deposited films of P3HT:PC ${ }_{60} \mathrm{BM}$ and P3HT: $\mathrm{IC}_{60} \mathrm{BA}$ films small P3HT domains (5 $\mathrm{nm}-10 \mathrm{~nm}$ width) distributed homogenously throughout the films were observed. $\mathrm{P} 3 \mathrm{HT}: \mathrm{PC}_{60} \mathrm{BM}$ films when annealed at $120^{\circ} \mathrm{C}$ show larger $\mathrm{P} 3 \mathrm{HT}$ domains aggregating together. When annealed at $150^{\circ} \mathrm{C}$ purer donor domains come together to form an interconnecting network. The donor purity was qualitatively analyzed by the enhanced contrast in the image. However in the case of as deposited and $120^{\circ} \mathrm{C}$ annealed P3HT:IC ${ }_{60} \mathrm{BA}$ films negligible change in donor purity or domain size was observed. When annealed at $150^{\circ} \mathrm{C}$ formation of interconnected domains was observed. Due to thickness variations in the blend films quantitative analysis was not feasible. From XRD results in Figure 1, it was shown that annealing above $80^{\circ} \mathrm{C}$ led to the improvement in crystallization of $\mathrm{P} 3 \mathrm{HT}$ domains in $\mathrm{P} 3 \mathrm{HT}: \mathrm{PC}_{60} \mathrm{BM}$ blend films. On the contrary, higher annealing temperatures $(>120 \mathrm{C})$ were required in P3HT:IC ${ }_{60} \mathrm{BA}$ films to enhance crystallization of P3HT phase. Correlating the XRD and EFTEM results it can be concluded that crystallization of $\mathrm{P} 3 \mathrm{HT}$ is the driving force to obtain higher purity polymer domains in the blend films consistent with the observation of other reports ${ }^{33-35}$. Hence $\mathrm{IC}_{60} \mathrm{BA}$ mixes with disordered or smaller crystallites of P3HT and further impedes crystallization of P3HT phase to a higher extent than $\mathrm{PC}_{60} \mathrm{BM}$. Such a different behavior could be attributed to several different reasons such as higher solubility, molecular structure, size of the molecule, diffusion coefficient in solid state or intermolecular attraction between $\mathrm{IC}_{60} \mathrm{BA}$ and $\mathrm{P} 3 \mathrm{HT}$. Our results with $\mathrm{P} 3 \mathrm{HT}: \mathrm{PC}_{70} \mathrm{BM}$ shows the same trend as $\mathrm{P} 3 \mathrm{HT}: \mathrm{PC}_{60} \mathrm{BM}$ even though $\mathrm{PC}_{70} \mathrm{BM}$ has higher solubility than $\mathrm{PC}_{60} \mathrm{BM}{ }^{36}$. Hence we believe that higher intermixing between $\mathrm{P} 3 \mathrm{HT}$ and $\mathrm{IC}_{60} \mathrm{BA}$ is not due to its higher solubility and real reason could be due to the physical properties of $\mathrm{IC}_{60} \mathrm{BA}$ molecule and is not clear yet. The rigid molecular structure of $\mathrm{IC}_{60} \mathrm{BA}$ due to two 
symmetrical indene groups could be one of the major reason that could impede diffusion at lower temperatures, however such a claim requires further experimental proof.
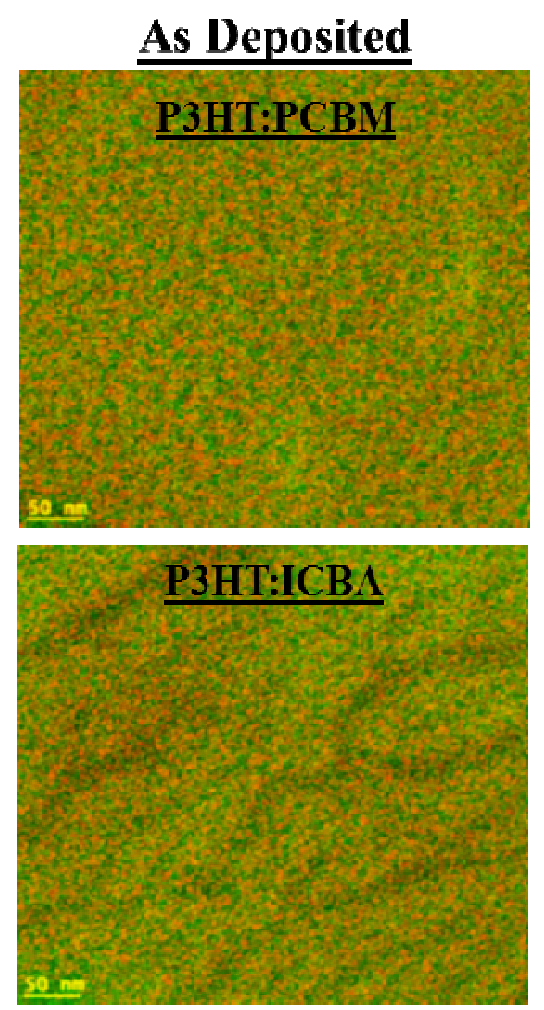
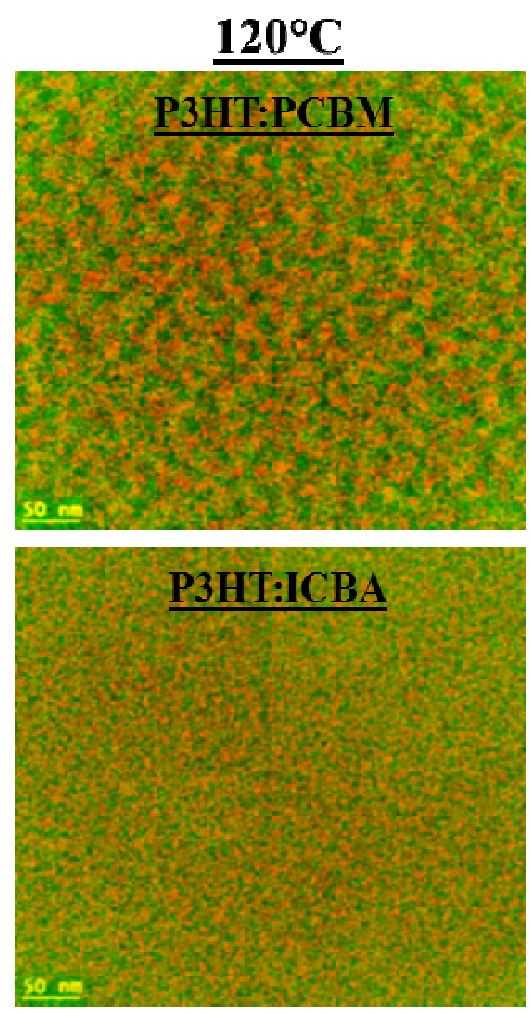
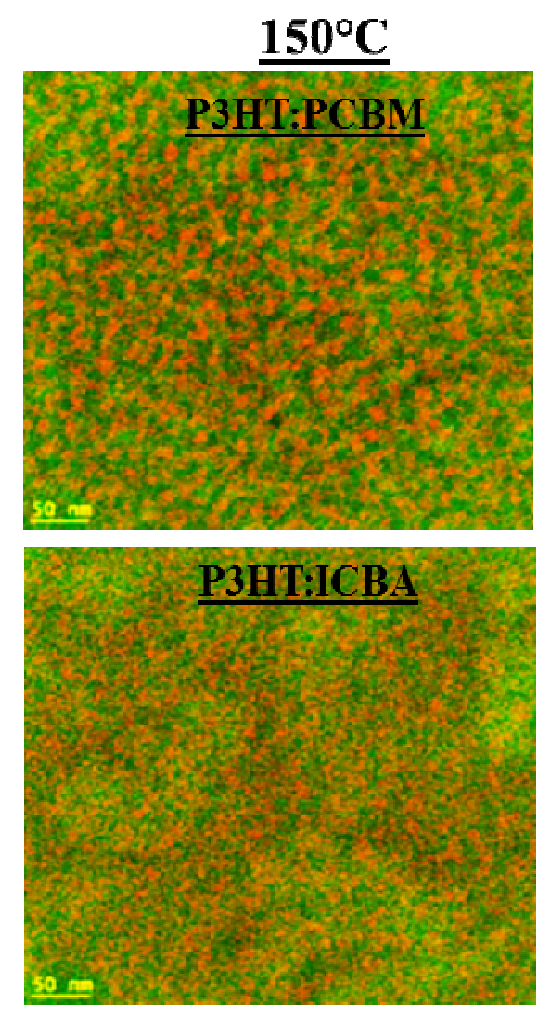

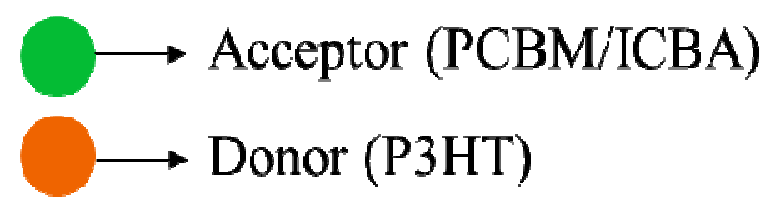

Figure 2 Energy filtered transmission electron microscopy (EFTEM) donor and acceptor composite maps of P3HT:PCBM and P3HT:ICBA thin films with different annealing temperatures

The current voltage characteristics of P3HT:PC ${ }_{60} \mathrm{BM}$ and $\mathrm{P} 3 \mathrm{HT}: \mathrm{IC}_{60} \mathrm{BA}$ solar cells with different active layer thermal annealing temperatures are shown in Figure $3 \mathrm{a}$ and $3 \mathrm{~b}$ respectively. As observed thermal annealing was essential to enhance the $\mathrm{J}_{\mathrm{sc}}$ and fill factor for both P3HT:PC ${ }_{60} \mathrm{BM}$ and P3HT: $\mathrm{IC}_{60} \mathrm{BA}$ solar cells. The photovoltaic parameters are tabulated in Table 1. The best efficiencies ( $\eta$ ) obtained for P3HT:PC ${ }_{60} \mathrm{BM}$ and $\mathrm{P} 3 \mathrm{HT}: \mathrm{IC}_{60} \mathrm{BA}$ are $3.08 \%$ and $4.19 \%$ respectively when the active layer was thermally annealed at $180{ }^{\circ} \mathrm{C}$. Higher $\mathrm{V}_{\mathrm{oc}} \mathrm{S}(\sim 0.25 \mathrm{~V})$ were observed for P3HT: $\mathrm{IC}_{60} \mathrm{BA}$ solar cells attributed to the higher LUMO level of $\mathrm{IC}_{60} \mathrm{BA}(3.74 \mathrm{eV})$ compared to that of $\mathrm{PC}_{60} \mathrm{BM}(3.91 \mathrm{eV})^{25,26,37}$. The dependence of $\mathrm{V}_{\mathrm{oc}}, \mathrm{J}_{\mathrm{sc}}, \mathrm{FF}$ and efficiency with 
annealing temperature is shown in Figure 4. There is a small reduction $(0.07 \mathrm{~V}-0.09 \mathrm{~V})$ in open circuit voltage with thermal annealing for both cases attributed to HOMO level shift formed as a result of improved P3HT crystallization ${ }^{38,39}$. In the case of P3HT:IC 60 BA the $\mathrm{J}_{\text {sc }}$ and FF showed higher dependence with annealing temperature. $\mathrm{J}_{\mathrm{sc}}$ increased from $1.66 \mathrm{~mA} / \mathrm{cm}^{2}$ to $6.22 \mathrm{~mA} / \mathrm{cm}^{2}$ when annealing temperature is increased from $80^{\circ} \mathrm{C}$ to $120^{\circ} \mathrm{C}$ and further increased with higher annealing temperatures till $180{ }^{\circ} \mathrm{C}$. However for P3HT:PC ${ }_{60} \mathrm{BM}$ bulk heterojunction solar cells $\mathrm{J}_{\mathrm{sc}}$ increased from $4.16 \mathrm{~mA} / \mathrm{cm}^{2}$ in as deposited active layers to $6.62 \mathrm{~mA} / \mathrm{cm}^{2}$ in $80^{\circ} \mathrm{C}$ annealed films. No significant change in $\mathrm{J}_{\mathrm{sc}}$ were observed higher annealing temperatures. Better performance in P3HT:PCBM cells is attributed to increase in fill factor increases with thermal annealing up to $180{ }^{\circ} \mathrm{C}$ and negligible decrease was observed when annealed at $200^{\circ} \mathrm{C}$. Photovoltaic efficiency trend with annealing temperature shows similar behavior as $\mathrm{J}_{\mathrm{sc}}$ with annealing temperature. Hence higher $\left(150^{\circ} \mathrm{C}-200^{\circ} \mathrm{C}\right)$ annealing temperatures was required to obtain comparable short circuit current density and photovoltaic efficiencies in P3HT:IC ${ }_{60} \mathrm{BA}$ solar cells.
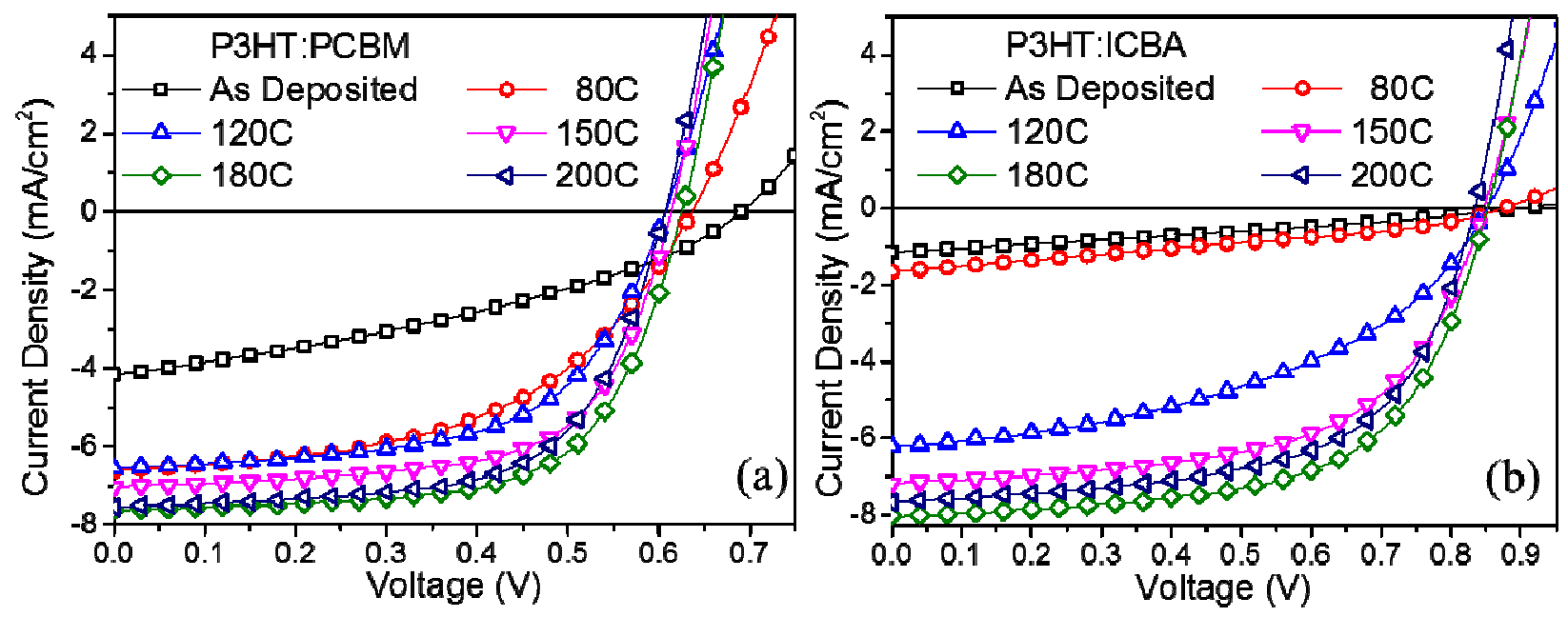

Figure 3 Current-voltage characteristics of (a) P3HT:PC ${ }_{60} \mathrm{BM}$ and (b) P3HT: $\mathrm{IC}_{60} \mathrm{BA}$ with different annealing temperature 
Table 1 Photovoltaic parameters of P3HT:PC ${ }_{60} \mathrm{BM}$ and P3HT:IC ${ }_{60} \mathrm{BA}$ solar cells

\begin{tabular}{|c|c|c|c|c|c|c|c|c|}
\hline \multirow[b]{2}{*}{$\begin{array}{l}\text { Annealing } \\
\text { Temperature }\end{array}$} & \multicolumn{4}{|c|}{ P3HT:PC ${ }_{60}$ BM } & \multicolumn{4}{|c|}{ P3HT:IC ${ }_{60}$ BA } \\
\hline & $\begin{array}{l}\mathbf{V}_{\text {oc }} \\
(\mathbf{V})\end{array}$ & $\begin{array}{c}\mathbf{J}_{\mathrm{sc}} \\
\left(\mathrm{mA} / \mathbf{c m}^{2}\right)\end{array}$ & FF & $\begin{array}{c}\eta \\
(\%)\end{array}$ & $\begin{array}{l}\mathbf{V}_{\text {oc }} \\
(\mathbf{V})\end{array}$ & $\begin{array}{c}\mathbf{J}_{\mathrm{sc}} \\
\left(\mathbf{m A} / \mathbf{c m}^{2}\right)\end{array}$ & $\mathbf{F F}$ & $\begin{array}{c}\eta \\
(\%)\end{array}$ \\
\hline As deposited & 0.69 & 4.16 & 0.36 & 1.03 & 0.90 & 1.15 & 0.29 & 0.30 \\
\hline $80^{\circ} \mathrm{C}$ & 0.64 & 6.62 & 0.50 & 2.14 & 0.88 & 1.66 & 0.31 & 0.46 \\
\hline $120^{\circ} \mathrm{C}$ & 0.61 & 6.56 & 0.58 & 2.33 & 0.85 & 6.22 & 0.45 & 2.40 \\
\hline $150^{\circ} \mathrm{C}$ & 0.61 & 7.03 & 0.65 & 2.77 & 0.85 & 7.18 & 0.58 & 3.57 \\
\hline $180^{\circ} \mathrm{C}$ & 0.63 & 7.64 & 0.64 & 3.08 & 0.85 & 8.04 & 0.61 & 4.19 \\
\hline $200^{\circ} \mathrm{C}$ & 0.61 & 7.55 & 0.63 & 2.90 & 0.83 & 7.68 & 0.60 & 3.84 \\
\hline
\end{tabular}
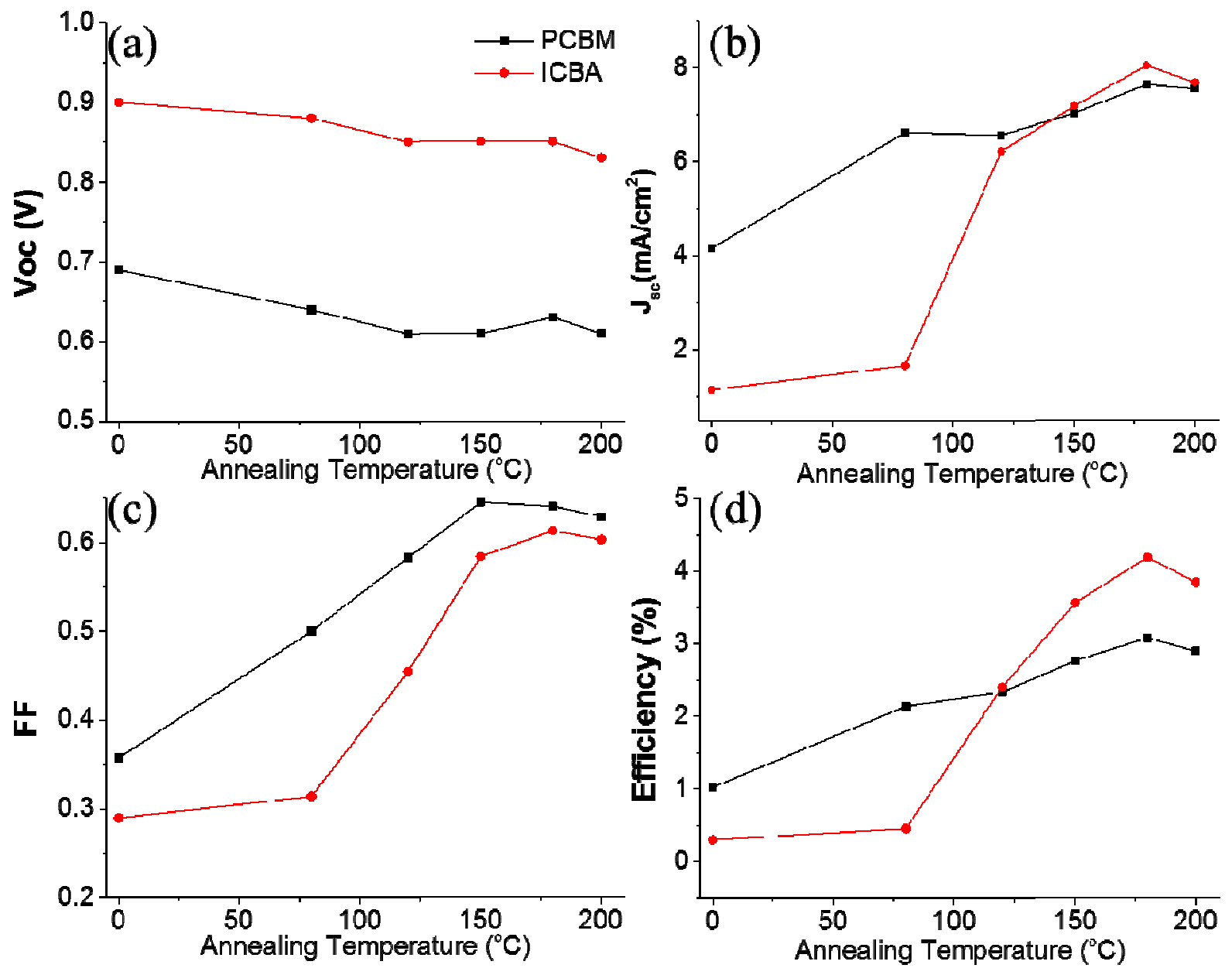

Figure 4 Effect of thermal annealing temperature on (a) Voc, (b) Jsc, (c) FF and (d) Efficiency on P3HT:PCBM and P3HT:ICBA solar cells 
Figure 5 shows the topography and phase images of the as deposited, $80^{\circ} \mathrm{C}$ and $150^{\circ} \mathrm{C}$ annealed P3HT:PC 60 BM and P3HT:IC ${ }_{60} \mathrm{BA}$ blend films. For the as deposited P3HT:PC ${ }_{60} \mathrm{BM}$ films fiber type morphology was seen in surface topography images whereas phase images shows both fiber type and agglomerated phases marked by dashed red circles in phase images. When P3HT:PC ${ }_{60} \mathrm{BM}$ films were annealed the root mean square (RMS) roughness values increase from $0.77 \mathrm{~nm}$ for the as deposited films to $0.81 \mathrm{~nm}$ for $80^{\circ} \mathrm{C}$ annealed films. The RMS roughness for $150^{\circ} \mathrm{C}$ annealed $\mathrm{P} 3 \mathrm{HT}: \mathrm{PC}_{60} \mathrm{BM}$ films is $1.001 \mathrm{~nm}$. Roughness increase is attributed to swelling of the films due to packing of polymer chains to form larger fiber-like morphology. This can be seen clearly in phase images of P3HT:PC 60 BM films when annealed. For P3HT: $\mathrm{IC}_{60} \mathrm{BA}$ samples the aggregated phases are observed in both topography and phase images of as deposited and $80^{\circ} \mathrm{C}$ annealed films. The aggregated phase is largest in the as deposited films and gets smaller for $80^{\circ} \mathrm{C}$ films. The RMS roughness increases from $0.53 \mathrm{~nm}$ for as deposited films to 0.608 films. For $150^{\circ} \mathrm{C}$ annealed films the RMS roughness was found to be $1.28 \mathrm{~nm}$ and showed fiber-like morphology. From XRD and optical absorption results, it was shown that $\mathrm{P} 3 \mathrm{HT}$ was more disordered and possessed smaller crystallites in $\mathrm{P} 3 \mathrm{HT}: \mathrm{PC}_{60} \mathrm{BM}$ and P3HT: $\mathrm{IC}_{60}$ BA films when no thermal annealing was applied. From EFTEM it was observed that in films without thermal annealing P3HT and fullerenes mix very well which led to low domain purity. It was also observed that low annealing temperatures $\left(\geq 80^{\circ} \mathrm{C}\right)$ were required for $\mathrm{P} 3 \mathrm{HT}: \mathrm{PC}_{60} \mathrm{BM}$ films however relatively higher temperatures $\left(\geq 120^{\circ} \mathrm{C}\right)$ were required in the case of P3HT:IC ${ }_{60} \mathrm{BA}$ films to enhance crystallization of P3HT. Based on this, the morphology evolution can be explained by taking into account following three different phases namely a) intermixed disordered polymer and fullerene phase b) crystalline polymer pure phase and c) fullerene nanocrystals or clusters. As deposited P3HT:PC ${ }_{60} \mathrm{BM}$ and P3HT:IC ${ }_{60} \mathrm{BA}$ films have higher intermixed polymer and fullerene phases that were observed in phase images as agglomerated regions marked by the dashed red circles. Upon thermal annealing of $\mathrm{P} 3 \mathrm{HT}: \mathrm{PC}_{60} \mathrm{BM}$ films at $80^{\circ} \mathrm{C} \mathrm{P} 3 \mathrm{HT}$ crystallized in fibrillar form and these agglomerated phase disappeared. Upon further annealing at $150^{\circ} \mathrm{C} \mathrm{PC}_{60} \mathrm{BM}$ phase possibly diffused to form clusters ${ }^{7}$ as seen in the regions marked by yellow dashed circles. For P3HT: $\mathrm{IC}_{60} \mathrm{BA}$ films the agglomerated phases regions were observed in both as deposited and $80^{\circ} \mathrm{C}$ annealed films attributed to higher degree of intermixing between disordered phase of P3HT and $\mathrm{IC}_{60} \mathrm{BA}$. Annealing at $150^{\circ} \mathrm{C}$ led to enhancement in $\mathrm{P} 3 \mathrm{HT}$ domain size to form interconnected fibers due 
to possible growth of $\mathrm{IC}_{60} \mathrm{BA}$ phase form clusters, $150 \mathrm{C}$ annealed $\mathrm{P} 3 \mathrm{HT}: \mathrm{IC}_{60} \mathrm{BA}$ showed similar morphology as of $150^{\circ} \mathrm{C}$ annealed $\mathrm{P} 3 \mathrm{HT}: \mathrm{PC}_{60} \mathrm{BM}$ films. Formation of fullerene clusters improved charge transport pathways and hence the fill factor as observed in the photovoltaic performance.

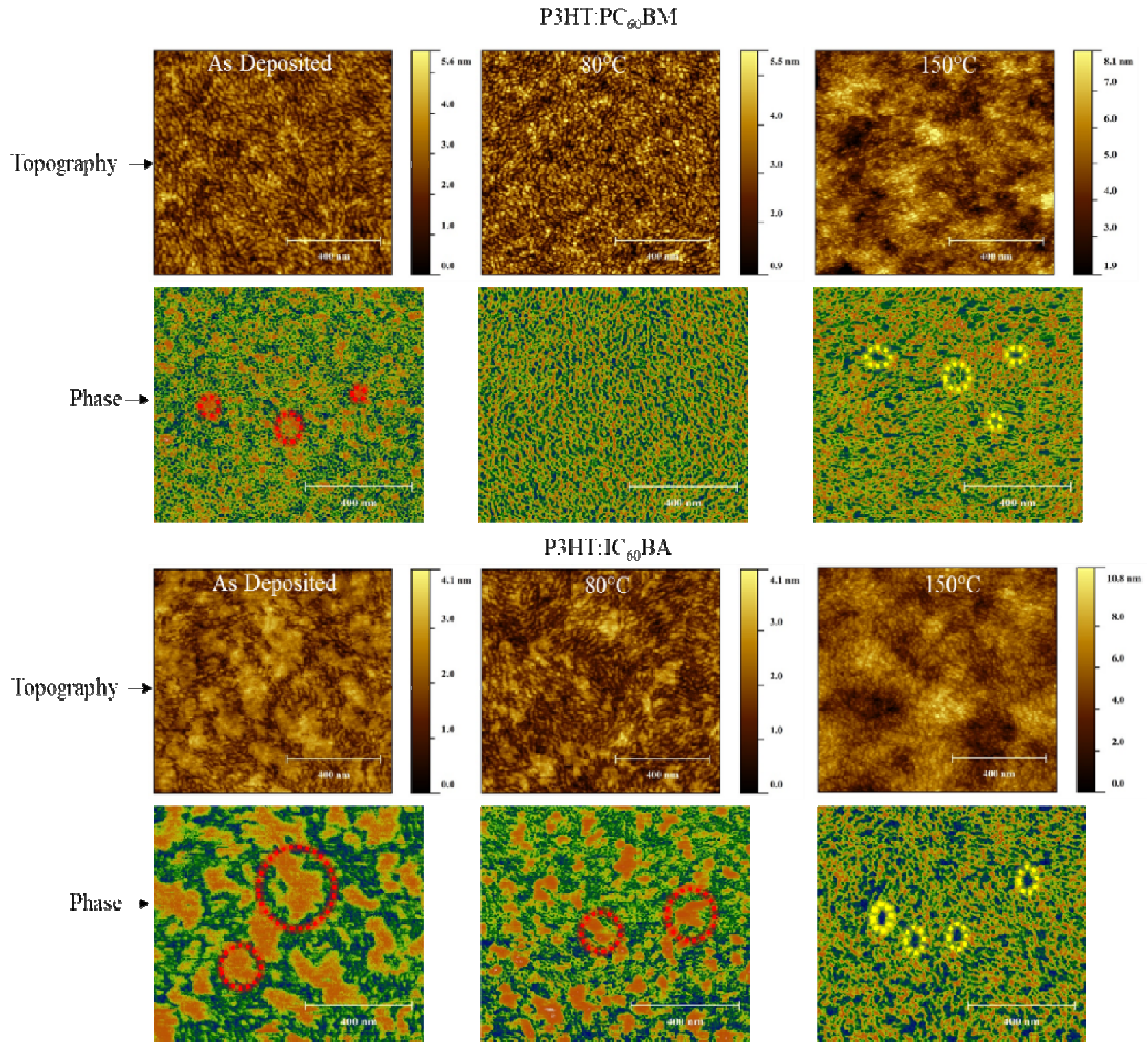

Figure 5 AFM topography and phase images of P3HT:PC ${ }_{60} \mathrm{BM}$ and P3HT: $\mathrm{IC}_{60} \mathrm{BA}$ films. Regions marked in red circles are indication of formation of intermixed phase. Regions marked in yellow circles are indication of formation of fullerene clusters

Further role of solvent additive namely nitrobenzene (NB) on the photovoltaic performance of $\mathrm{P} 3 \mathrm{HT}: \mathrm{PC}_{60} \mathrm{BM}$ and $\mathrm{P} 3 \mathrm{HT}: \mathrm{IC}_{60} \mathrm{BA}$ cells were studied and compared with best annealed devices as shown in Figure 6.4 and 2 volume percent $\mathrm{NB}$ was added to P3HT:PC ${ }_{60} \mathrm{BM}$ 
and P3HT: $\mathrm{IC}_{60} \mathrm{BA}$ blend solutions respectively before spin coating the active layers. $180^{\circ} \mathrm{C}$ was chosen as the annealing temperature for comparison and termed as 'Annealed' in all the future sections. It is obvious that $\mathrm{NB}$ additive improved the $\mathrm{J}_{\mathrm{sc}}$ of solar cells with minor changes in $\mathrm{V}_{\mathrm{oc}}$ and $\mathrm{FF}$ in both P3HT:PC ${ }_{60} \mathrm{BM}$ and $\mathrm{P} 3 \mathrm{HT}: \mathrm{IC}_{60} \mathrm{BA}$ cells when compared to annealed devices. The power conversion efficiencies were enhanced to $4.32 \%$ and $5.77 \%$ with the addition of NB in P3HT: $\mathrm{PC}_{60} \mathrm{BM}$ and P3HT:IC ${ }_{60} \mathrm{BA}$ solar cells respectively. The photovoltaic parameters are tabulated in Table 2. The dark curves are shown in supporting information and it is observed that NB modified devices possessed lower saturation current density as well as lower ideality factor than annealed and as deposited devices. Ideality factor has been linked to energy disorder in bulk heterojunction solar cells ${ }^{40}$, hence addition of NB could lower the energy disorder in the active layers.
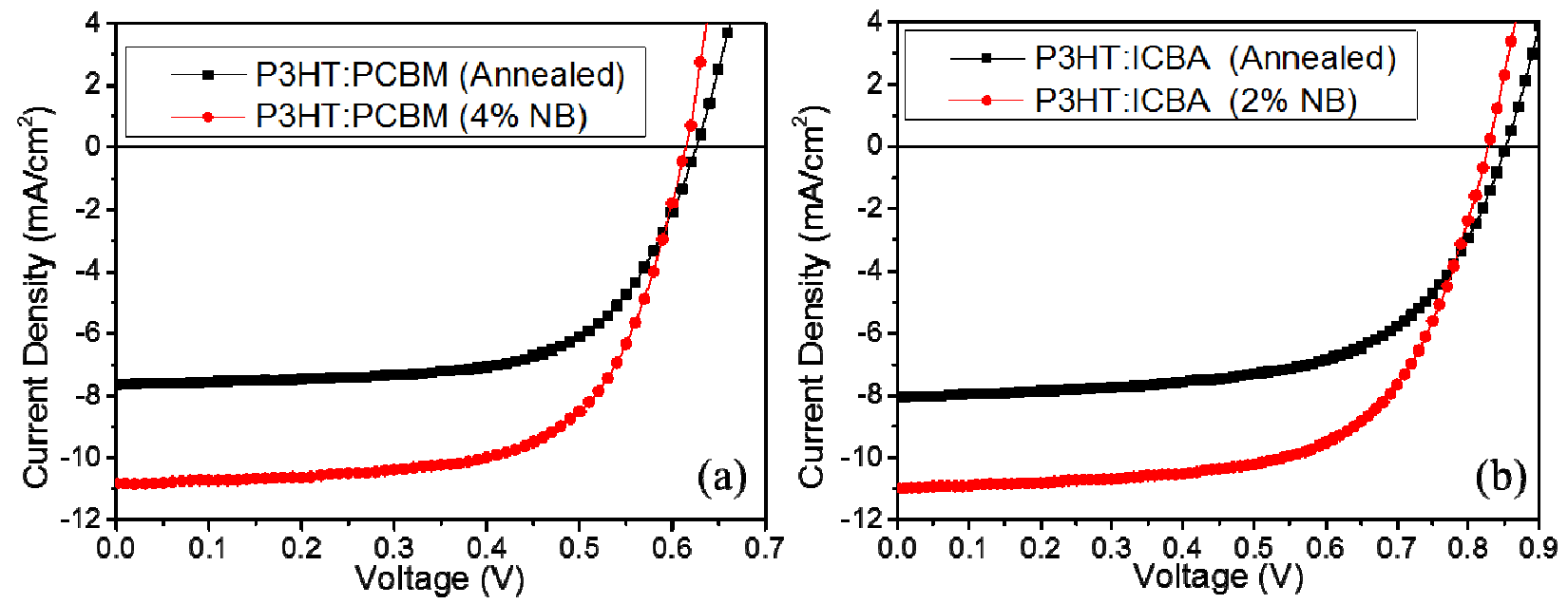

Figure 6 Current-voltage characteristics of thermally annealed and solvent additive modified $\mathrm{P} 3 \mathrm{HT}: \mathrm{PC}_{60} \mathrm{BM}$ and (b) P3HT: $\mathrm{IC}_{60} \mathrm{BA}$ solar cells 
Table 2 Photovoltaic parameters of thermally annealed and NB modified P3HT:PC ${ }_{60} \mathrm{BM}$ and P3HT: $\mathrm{IC}_{60} \mathrm{BA}$ solar cells

\begin{tabular}{|c|c|c|c|c|c|}
\hline & $\begin{array}{c}\mathbf{V}_{\text {oc }} \\
(\mathbf{V})\end{array}$ & $\begin{array}{c}\mathbf{J}_{\text {sc }} \\
\left(\mathbf{m A} / \mathbf{c m}^{\mathbf{2}}\right)\end{array}$ & $\begin{array}{c}\text { Fill } \\
\text { Factor }\end{array}$ & $\begin{array}{c}\text { Efficiency } \\
(\%)\end{array}$ & $\begin{array}{c}\text { Enhancement } \\
(\%)\end{array}$ \\
\hline $\begin{array}{c}\text { P3HT:PCBM - } \\
\text { Annealed }\end{array}$ & 0.63 & 7.64 & 0.64 & 3.08 & - \\
\hline P3HT:PCBM - 4\% NB & 0.61 & 10.83 & 0.65 & 4.32 & 40.26 \\
\hline P3HT:ICBA - Annealed & 0.85 & 8.04 & 0.61 & 4.19 & - \\
\hline P3HT:ICBA - 2\% NB & 0.83 & 10.99 & 0.63 & 5.77 & 37.71 \\
\hline
\end{tabular}

To investigate the reasoning behind effect of NB on enhanced photovoltaic performance, the morphology was characterized by EFTEM and Kelvin probe force microscopy (KPFM) and compared with as deposited and annealed samples as shown in Figure 7. EFTEM images showed highly intermixed domains in as deposited samples and upon thermal annealing the domain purity increased. Addition of NB additives enhanced the P3HT domain purity with larger interconnected domains as observed from the higher sulfur contrast in EFTEM images. KPFM images of as deposited showed large aggregates $(\sim 100 \mathrm{~nm}-150 \mathrm{~nm}$ diameter $)$ of higher surface potential and fiber-like morphology ( $20 \mathrm{~nm}$ mean diameter) as matrix. The RMS surface potential variation of as deposited films was $17.3 \mathrm{mV}$. In annealed film distinct fiber like domains ( $15 \mathrm{~nm}$ mean diameter) were observed with smaller aggregates $(\sim 40 \mathrm{~nm}-55 \mathrm{~nm}$ diameter). The RMS surface potential variation for annealed films increased to $27.5 \mathrm{mV}$. In the case of NB casted films predominantly fiber type of morphology was observed having average diameter of $20 \mathrm{~nm}$ and RMS variation of $41.4 \mathrm{mV}$. The length scales observed for features in annealed and NB films were consistent with the length scales of pure P3HT domains observed in EFTEM images. To further analyze the KPFM images of the films, surface potential distribution and line profiles were plotted as shown in Figure 7c and 7d. For the as deposited films, a narrow distribution is observed having full width half maximum (FWHM) of 40mV. For annealed and NB modified films, a broader distribution is observed having FWHM of $64 \mathrm{mV}$ and $74 \mathrm{mV}$ respectively were observed. Line profile variation of surface potential showed that as deposited films had the least variation over length. Annealed films showed higher variation and NB modified films showed the highest variation in surface potential. From EFTEM and KPFM 
images it can be concluded that NB additive enhanced the domain purity that led to enhanced interfacial potential variation due to less intermixing at domain interfaces. No change in crystallite size was observed in XRD spectra of NB modified films (Supporting Information Figure 3). However optical absorption showed pronounced vibronic shoulders and red shift for films cast with NB additive. This discrepancy could be due to packing orientation of P3HT chains which might not be sensitive to $\mathrm{Cu} \mathrm{Ka} \mathrm{X-rays.} \mathrm{Further} \mathrm{insight} \mathrm{is} \mathrm{needed} \mathrm{on} \mathrm{the} \mathrm{structural}$ arrangement caused by NB addition and will be carried out in future. Nevertheless, Nitrobenzene (NB) effectively controlled the morphology of polymer-fullerene blends as it selectively solubilized the fullerene and induced self-ordering of purer polymer phase. Due to this selective solubility, blend films cast with NB additive possessed homogeneous interpenetrating network of nanoscale phase separated domains. Thermal annealing also induced crystallization of polymer but due to local inhomogeneity in domain purity ${ }^{41}$ and lack of free energy for diffusion of polymer or fullerene, homogenous phase separation between them was not achieved. 
(a)
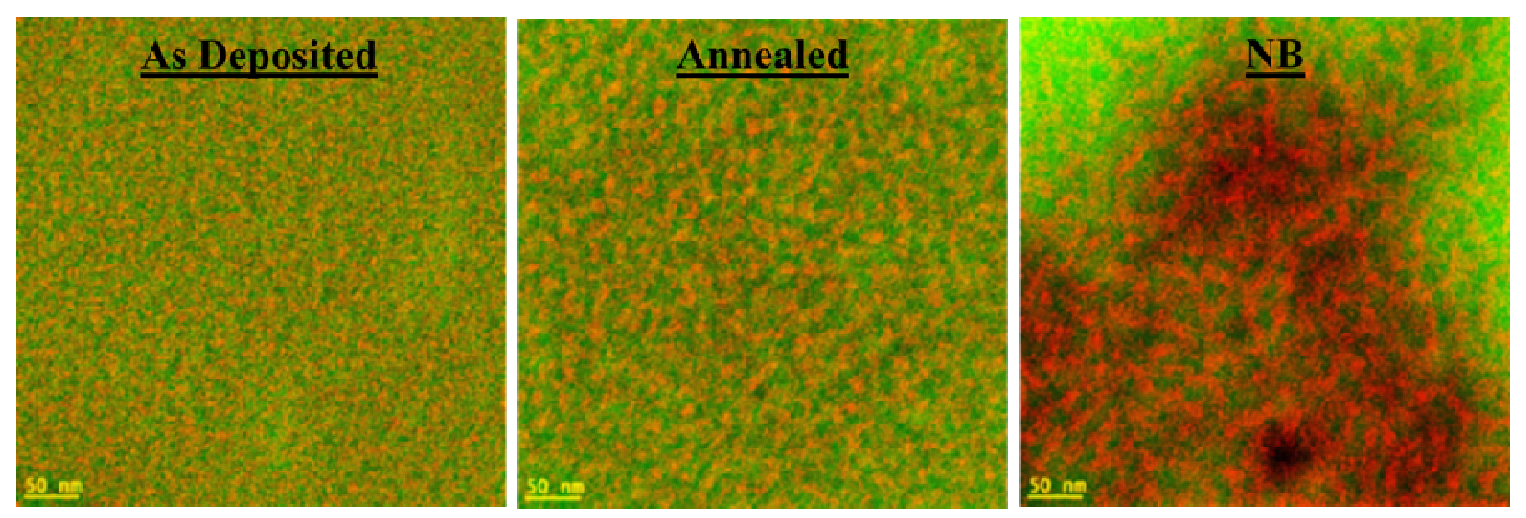

(b)
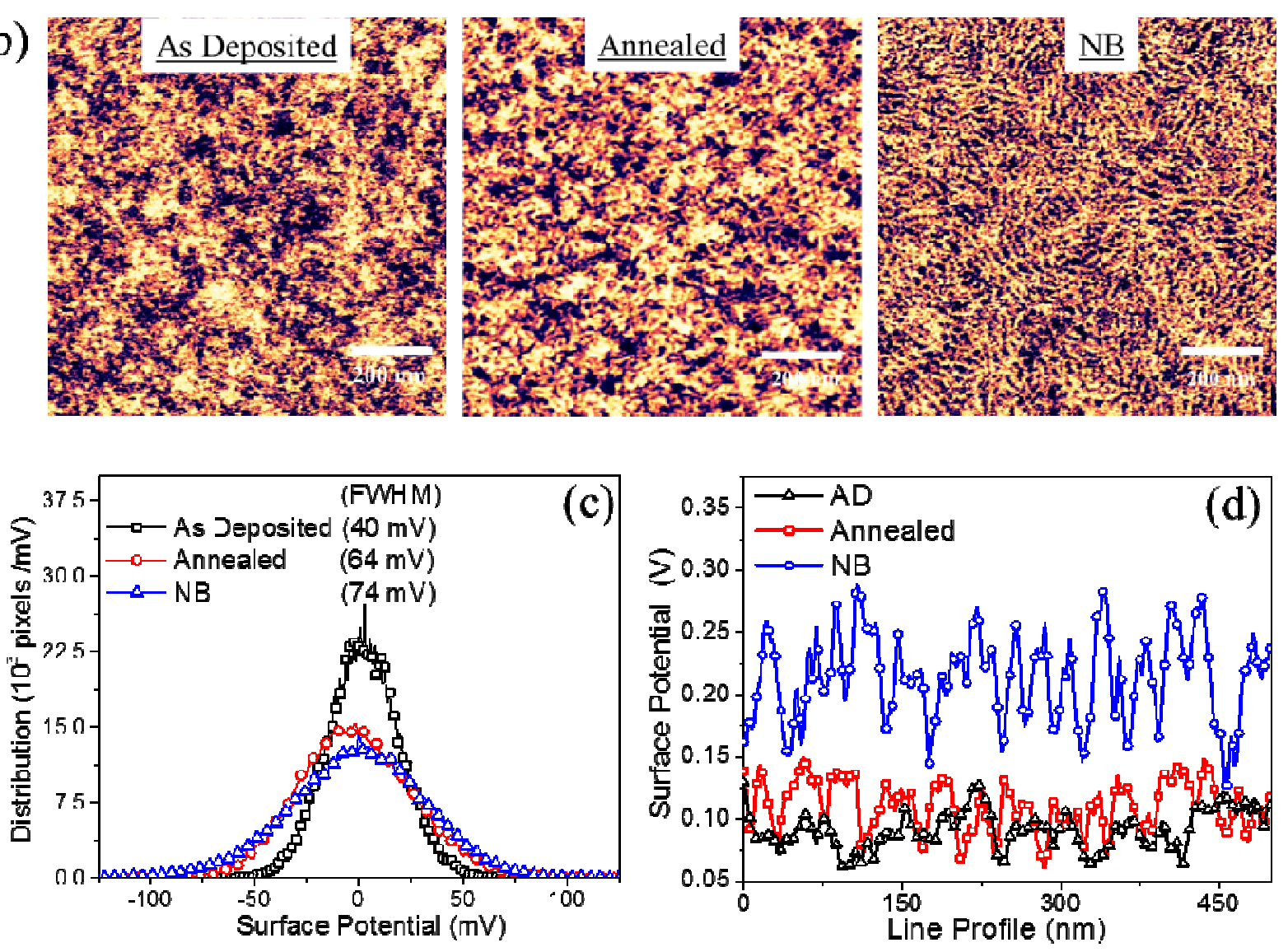

Figure 7 (a) EFTEM donor and acceptor composite maps of P3HT:PC ${ }_{60} \mathrm{BM}$ films (b) Kelvin probe force microscopy images of $\mathrm{P} 3 \mathrm{HT}: \mathrm{PC}_{60} \mathrm{BM}$ thin films (c) Pixel distribution of surface potential from KPFM images of P3HT: $\mathrm{PC}_{60} \mathrm{BM}$ thin films. Values in parenthesis show the full width half maximum (FWHM) of Gaussian fits. (d) Line profiles of of P3HT:PC ${ }_{60} \mathrm{BM}$ thin films

To evaluate the charge density and lifetime transient photocurrent (TPC) and photovoltage (TPV) spectroscopy were done on as deposited, annealed and NB modified solar cells. From TPV measurements, the charge carrier lifetime were measured with increasing light intensities which led to different $V_{\text {oc }}$ in the cells as shown in Figure 8a. Charge carrier lifetime 
decreases with increasing $\mathrm{V}_{\mathrm{oc}}$ attributed to higher bimolecular recombination in the cells at higher light intensity. For the as deposited cells the charge carrier lifetime decreased to a much higher extent at higher $\mathrm{V}_{\mathrm{oc}} \mathrm{s}$ than annealed and $\mathrm{NB}$ modified devices. At 1 sun condition when the cell reaches the optimum $\mathrm{V}_{\mathrm{oc}}$ the measured lifetime for as deposited, annealed and NB modified cells are $1.57 \mu \mathrm{s}, 3.87 \mu \mathrm{s}$ and $5.17 \mu \mathrm{s}$ respectively. Charge carrier lifetimes were plotted as a function of charge carrier density as shown in $8 \mathrm{~b}$. As deposited cells showed the lowest charge carrier density $\left(\sim 10^{16} \mathrm{~cm}^{-3}\right)$ among all cells which decreased rapidly with increasing charge carrier density. For annealed devices, the charge carrier density increased by almost two orders of magnitude compared to as deposited cells. NB modified devices showed higher charge carrier density with lowest decline in lifetime. The slope of the linear region in charge carrier density vs lifetime plots was measured to evaluate the bimolecular recombination order. The bimolecular recombination order obtained for as deposited, annealed and NB modified devices are 8.02, 4.9 and 1.8 respectively. Higher interfacial potential variation in NB modified devices led to efficient exciton dissociation and suppressed interfacial bimolecular recombination ${ }^{23,42}$. Charge carrier mobility was evaluated using photo-charge carrier extraction by linearly increasing voltage (Photo-CELIV) technique. The Photo-CELIV at $10 \mu$ s delay time for as deposited, annealed and NB modified solar cells are shown in Figure 8c. The PhotoCELIV current signal approached maximum earlier (lower $t_{\max }$ ) in NB modified cells than annealed devices. The as deposited samples had the highest $\mathrm{t}_{\max }$ of $5.35 \mu \mathrm{s}$ among all solar cells. $\mathrm{t}_{\mathrm{max}}$ for annealed and NB cells were $4.7 \mu$ s and $3.4 \mu$ s respectively. Since the same voltage ramp was used for all cells lower $t_{\max }$ is related to lower bias voltage (field) required to extract the maximum charge carriers from the device. NB modified solar cells showed the highest mobility of $4.81 \times 10^{-5} \mathrm{~cm}^{2} /$ Vs and also resulted in the highest extracted charge carriers $\left(\mathrm{n}_{\text {ext }}\right)$ of $4.35 \times 10^{16}$ $\mathrm{cm}^{-3}$. 

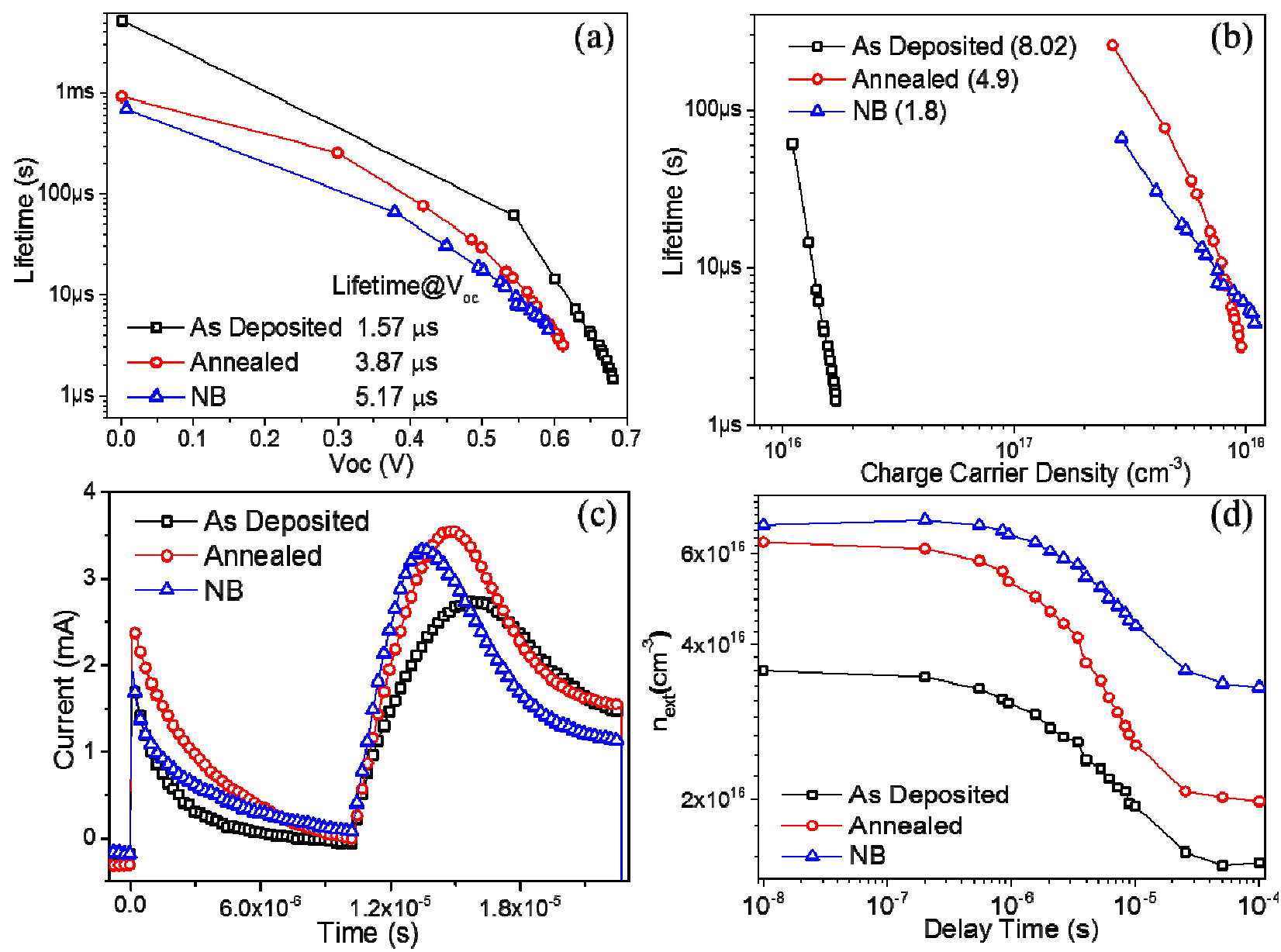

Figure 8 Charge carrier lifetime as a function of (a) open circuit voltage and (b) charge carrier density. The values in the legend of (a) and (b) show the charge carrier lifetime at 1 sun Voc and bimolecular recombination order respectively. (c) Photo-CELIV spectra of P3HT:PC 60 BM solar cells at $10 \mu$ s delay time between light pulse and voltage ramp, and (d) extracted charge carrier density $\left(\mathrm{n}_{\mathrm{ext}}\right)$ from photo - CELIV curves with varying delay times.

\section{Conclusions}

Bulk heterojunction solar cells were fabricated with two different fullerene derivatives and the effect of thermal annealing on the active layer morphology and device performance was studied. It is seen that higher thermal annealing temperatures were needed for $\mathrm{IC}_{60} \mathrm{BA}$ compared to $\mathrm{PC}_{60} \mathrm{BM}$ for obtaining enhanced photovoltaic efficiency. The increase in efficiency was due to increased short circuit current density and fill factor. Increase in short circuit current density and fill factor is attributed to the polymer crystallization and formation of fullerene clusters respectively. Higher thermal annealing temperature was required for P3HT crystallization in 
P3HT: $\mathrm{IC}_{60} \mathrm{BA}$ blends due to higher intermixing between $\mathrm{P} 3 \mathrm{HT}$ and $\mathrm{IC}_{60} \mathrm{BA}$. Domain purity was observed to increase when crystalline $\mathrm{P} 3 \mathrm{HT}$ domains existed suggesting that fullerene mixing is only with disordered P3HT. It is well known that fullerene molecules cannot thermodynamically exist in between crystalline P3HT chains. In this case it was found that degree of mixing is dependent upon the fullerene derivative used which dictated the thermal energy required for adequate phase separation between pure polymer and acceptor phases. Further role of solvent additive on the device performance was evaluated and it was observed that small concentration (2-4 volume percent) of solvent additive (NB) significantly enhanced the short circuit current density that led to higher device efficiency. Detailed insight into domain purity and nanoscale surface potential variation was provided and compared for three different cases - as deposited, annealed and NB additive modified solar cells. It was observed that NB modified blends had higher domain purity consisting of interconnected crystalline P3HT domains. Higher domain purity led to sharper interfaces giving rise to higher surface potential variation. Due to these sharper interfaces, NB modified devices showed suppressed bimolecular recombination and enhanced charge carrier mobility and lifetime when compared to thermally annealed and as deposited solar cells. Addition of NB led to a morphology ideal for high efficiency bulk heterojunction solar cells as it gives rise to lesser energetic disorder and effective charge transport pathways. This led to less effective charge transport pathways due to the presence of impure domains which act as sinks for recombination. Hence inclusion of solvent additive provides a simple and effective technique to improve photovoltaic device efficiency of bulk heterojunction solar cells.

\section{Acknowledgement}

We acknowledge the support from NASA EPSCoR (NNX13AD31A), NSF CAREER (ECCS-0950731), and NSF MRI (grant no. 1229577). TEM experiments were conducted at the Center for Nanophase Materials Sciences, which was sponsored at Oak Ridge National Laboratory by the Division of Scientific User Facilities, Office of Basic Energy Sciences, U.S. Department of Energy. 


\section{References}

1. T. P. Osedach, T. L. Andrew and V. Bulovic, Energy Environ. Sci., 6 (2013) 711-718.

2. M. Kaltenbrunner, M. S. White, E. D. Głowacki, T. Sekitani, T. Someya, N. S. Sariciftci and S. Bauer, Nat Commun, 3 (2012) 770.

3. C.-C. Chen, W.-H. Chang, K. Yoshimura, K. Ohya, J. You, J. Gao, Z. Hong and Y. Yang, Advanced Materials, 26 (2014) 5670-5677.

4. M. A. Green, K. Emery, Y. Hishikawa, W. Warta and E. D. Dunlop, Prog. Photovolt: Res. Appl., 22 (2014) 701-710.

5. W. Chen, T. Xu, F. He, W. Wang, C. Wang, J. Strzalka, Y. Liu, J. Wen, D. J. Miller, J. Chen, K. Hong, L. Yu and S. B. Darling, Nano Lett., 11 (2011) 3707-3713.

6. $\quad$ S. Günes, H. Neugebauer and N. S. Sariciftci, Chem. Rev., 107 (2007) 1324-1338.

7. M. Campoy-Quiles, T. Ferenczi, T. Agostinelli, P. G. Etchegoin, Y. Kim, T. D. Anthopoulos, P. N. Stavrinou, D. D. C. Bradley and J. Nelson, Nat. Mater., 7 (2008) 158164.

8. L. Chang, H. W. A. Lademann, J.-B. Bonekamp, K. Meerholz and A. J. Moulé, Adv. Funct. Mater., 21 (2011) 1779-1787.

9. M. Shao, J. K. Keum, R. Kumar, J. Chen, J. F. Browning, S. Das, W. Chen, J. Hou, C. Do, K. C. Littrell, A. Rondinone, D. B. Geohegan, B. G. Sumpter and K. Xiao, Adv. Funct. Mater. (2014) n/a-n/a.

10. C.-G. Wu, C.-H. Chiang and H.-C. Han, J. Mater. Chem. A, 2 (2014) 5295-5303.

11. B. Huang, J. A. Amonoo, A. Li, X. C. Chen and P. F. Green, J. Phys. Chem. C, 118 (2014) 3968-3975.

12. W. Ma, J. R. Tumbleston, M. Wang, E. Gann, F. Huang and H. Ade, Adv. Energy Mater., 3 (2013) 864-872.

13. L. Ye, S. Zhang, W. Ma, B. Fan, X. Guo, Y. Huang, H. Ade and J. Hou, Advanced Materials, 24 (2012) 6335-6341.

14. Y. Yao, J. Hou, Z. Xu, G. Li and Y. Yang, Adv. Funct. Mater., 18 (2008) 1783-1789.

15. S. Venkatesan, N. Adhikari, J. Chen, E. C. Ngo, A. Dubey, D. W. Galipeau and Q. Qiao, Nanoscale, 6 (2014) 1011-1019.

16. L. H. Nguyen, H. Hoppe, T. Erb, S. Günes, G. Gobsch and N. S. Sariciftci, Adv. Funct. Mater., 17 (2007) 1071-1078.

17. S. A. Hawks, F. Deledalle, J. Yao, D. G. Rebois, G. Li, J. Nelson, Y. Yang, T. Kirchartz and J. R. Durrant, Adv. Energy Mater., 3 (2013) 1201-1209.

18. S. Venkatesan, E. C. Ngo, Q. Chen, A. Dubey, L. Mohammad, N. Adhikari, A. F. Mitul and Q. Qiao, Nanoscale, 6 (2014) 7093-7100.

19. B. A. Collins, E. Gann, L. Guignard, X. He, C. R. McNeill and H. Ade, J. Phys. Chem. Lett., 1 (2010) 3160-3166.

20. F. C. Jamieson, E. B. Domingo, T. McCarthy-Ward, M. Heeney, N. Stingelin and J. R. Durrant, Chemical Science, 3 (2012) 485-492.

21. B. P. Lyons, N. Clarke and C. Groves, Energy Environ. Sci., 5 (2012) 7657-7663.

22. B. A. Collins, J. R. Tumbleston and H. Ade, J. Phys. Chem. Lett., 2 (2011) 3135-3145.

23. B. A. Collins, Z. Li, J. R. Tumbleston, E. Gann, C. R. McNeill and H. Ade, Adv. Energy Mater., 3 (2013) 65-74.

24. M. T. Dang, L. Hirsch and G. Wantz, Advanced Materials, 23 (2011) 3597-3602.

25. G. Zhao, Y. He and Y. Li, Advanced Materials, 22 (2010) 4355-4358. 
26. Y.-J. Cheng, C.-H. Hsieh, Y. He, C.-S. Hsu and Y. Li, J. Am. Chem. Soc., 132 (2010) 17381-17383.

27. I. Burgues-Ceballos, M. Stella, P. Lacharmoise and E. Martinez-Ferrero, J. Mater. Chem. A (2014).

28. H. Chen, J. Peet, Y.-C. Hsiao, B. Hu and M. Dadmun, Chem. Mater., 26 (2014) 39934003.

29. J. Jo, S.-S. Kim, S.-I. Na, B.-K. Yu and D.-Y. Kim, Adv. Funct. Mater., 19 (2009) 866874.

30. F.-C. Chen, C.-J. Ko, J.-L. Wu and W.-C. Chen, Sol. Energy Mater. Sol. Cells, 94 (2010) 2426-2430.

31. J. Liu, S. Shao, H. Wang, K. Zhao, L. Xue, X. Gao, Z. Xie and Y. Han, Org. Electron., 11 (2010) 775-783.

32. W. Ma, C. Yang, X. Gong, K. Lee and A. J. Heeger, Adv. Funct. Mater., 15 (2005) 16171622.

33. M. A. Brady, G. M. Su and M. L. Chabinyc, Soft Matter, 7 (2011) 11065-11077.

34. N. D. Treat, M. A. Brady, G. Smith, M. F. Toney, E. J. Kramer, C. J. Hawker and M. L. Chabinyc, Advanced Energy Materials, 1 (2011) 82-89.

35. D. R. Kozub, K. Vakhshouri, L. M. Orme, C. Wang, A. Hexemer and E. D. Gomez, Macromolecules, 44 (2011) 5722-5726.

36. D. T. Duong, B. Walker, J. Lin, C. Kim, J. Love, B. Purushothaman, J. E. Anthony and T.-Q. Nguyen, J. Polym. Sci., Part B: Polym. Phys., 50 (2012) 1405-1413.

37. Y. He, H.-Y. Chen, J. Hou and Y. Li, Journal of the American Chemical Society, 132 (2010) 1377-1382.

38. K. S. Nalwa, R. C. Mahadevapuram and S. Chaudhary, Appl. Phys. Lett., 98 (2011) -.

39. K. Vandewal, W. D. Oosterbaan, S. Bertho, V. Vrindts, A. Gadisa, L. Lutsen, D. Vanderzande and J. V. Manca, Appl. Phys. Lett., 95 (2009) -.

40. G. Garcia-Belmonte, Solid-State Electronics, 79 (2013) 201-205.

41. A. J. Moulé and K. Meerholz, Advanced Materials, 20 (2008) 240-245.

42. M.-S. Su, C.-Y. Kuo, M.-C. Yuan, U. S. Jeng, C.-J. Su and K.-H. Wei, Advanced Materials, 23 (2011) 3315-3319. 
Graphical abstract

Donor and acceptor composite mapping of energy filtered transmission electron microscopy (EFTEM) measurement in P3HT:PCBM and P3HT:ICBA thin films with different annealing temperatures.
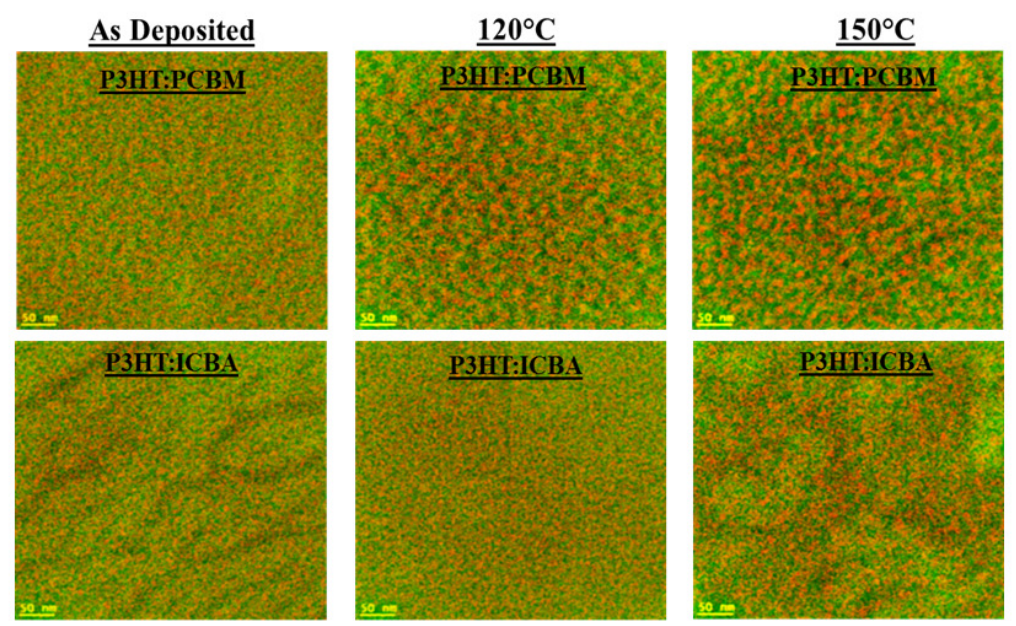

$\longrightarrow$ Acceptor $(\mathrm{PCBM} / \mathrm{ICBA})$

Donor (P3HT) 